\title{
A Flight Within: Keat's Nightingale In Light of the Sufis
}

\author{
Hend Hamed Ezzeldin*
}

Faculty of Al-Alsun, Ain Shams University, Egypt

Corresponding Author: Hend Hamed Ezzeldin, E-mail: hendhamed@alsun.asu.edu.eg

\section{ARTICLE INFO}

Article history

Received: March 05, 2018

Accepted: April 30, 2018

Published: June 30, 2018

Volume: 9 Issue: 3

Advance access: May 2018

Conflicts of interest: None

Funding: None

Key words:

Sufism,

Romanticism,

Annihilation,

Nightingale,

Keats,

Spirituality

\begin{abstract}
Sufism is the mode of religious life in Islam in which emphasis is placed on the activities of the inner self than external rituals and performances. The essence of Sufism lies in its internal transcendental experience. The aim of Sufis is to delve into the human soul and see through its darkness in order to reach the ultimate truth. Sufi poetry is abundant with images that present the human soul as a mystery that could be decrypted via contemplation, meditation, and inner vision. The target of Sufis is to reunite with the Universal Self that is the 'truer' self of every human (i.e. God). Likewise, Romanticism is founded on the doctrine that all creation began in harmonious unity. Romantic poets share Sufis' quest for truth and an illuminating path towards reaching the essence of the Divine. A renowned Romantic poet, John Keats, contrary to his fellow Romantics, never alluded to sharing any interest with the orient or the spirituality it incarnates. However, by attempting a Sufi reading of his poem 'Ode to a Nightingale', this research paper will attempt to highlight the underlying philosophy and uncover the spiritual implications hidden within Keats' ode and propound a solid connection between Sufi and Romantic ideologies.
\end{abstract}

\section{INTRODUCTION}

Interest in the Orient has always been a main feature of European writings. Seen as a far-distant other, many writers, throughout the $18^{\text {th }}$ and the $19^{\text {th }}$ centuries, created a large body of literature, either translating or adapting from original oriental texts. Authors from France, Austria, and Britain bore the responsibility of conveying the messages of Oriental literature to the Western readers. In her book Borrowed Imagination: The British Romantic Poets and the Arabic-Islamic Sources, Samar Attar stresses the profound influence of Arabic works on the Romantics and regrets that these influences were not explored by European scholars. In addition to The Arabian Nights, other sources were available to the Romantic writers in abundance such as "pre-Islamic poetry, Arabic history and literature, Muslim mystic poetry, and numerous oriental tales" (Attar 14). Persian Sufi literature had its immense impact on the Romantics as well; as through this literature interest in the Orient was risen. In his article "Persian Sufi Literature: Its Spiritual and Cultural Significance”, Hossein Nasr maintains that "it was the universal spiritual appeal of Persian Literature and the effect that the inner meaning of the Quran and the spirituality of the Persians that attracted some of the late $18^{\text {th }}$ century and early $19^{\text {th }}$ century Orientalists at the beginning of contact between the Romantic movement in Europe and the culture of the Islamic world" (2). Nasr claims that the "appeal of Sufism in Europe is to a remarkable extent due to the writings of Persian Sufi poets and philosophers such as Sana'i, Maulavi (Rumi), Attar, Sa'adi, Hafez, Mahmud Shabestari, Shah Ne'matollah Wali, and Jami" (3). For example, in 1807, when Lord Byron was only 19 years, he made a list of the books that he had read. This list included, among others, "Arabia-Mahomet, whose Koran contains most sublime poetical passages, far surpassing European poetry. Persian Ferdousi, author of Shah Nameh, the Persian Iliad, - Sadi and Hafiz, the Oriental Anacreon" (Moore). Islam was, thence, a "spiritual resource for Romantic writers, and Sufism in particular played a role in this stimulation" (Einboden 7). This paper aims to explore John Keats' 'Ode to a Nightingale' from a Sufi perspective attempting to translate his inner journey into spiritual, Sufi terms to showcase a Romantic self that has deep passion in spiritualism and transcendentalism.

\section{${ }^{1}$ Sufism in Romanticism}

Although centuries apart, these disparate theological, philosophical and mystical movements (Sufism and Romanticism) share specific 'archetypal themes' that could hardly be 
dismissed. The term 'Sufism' came to light in the $19^{\text {th }}$ century as 'tasawouf'. The word comes from 'suf' (wool), a reference to the woolen garments worn by early Sufis. Etymologically, the word 'sufi' is derived from 'safa' (which means purity), or it could be associated with 'saff' (which means rank) as though the Sufis were the ones selected to become purified from all worldly defilements or as though they were spiritually first-ranked in virtue of their communion with God (Stoddart 1). Tasawouf, in addition, denotes "a path, a journey, a journey of the heart. Such a journey has a beginning; a point of departure that leads towards a destination. A Sufi takes an inner journey to attain the knowledge of self, a knowledge that leads towards understanding the Divine" (Angha). A Sufi is a mystic, a person who endeavors towards intimate knowledge or unity with God through contemplation, meditation, and inner vision. Since its beginnings, Sufism has been called the 'knowledge of hearts' or the 'knowledge of spiritual states'. Being 'the knowledge of the inner (ilm al-batin), as opposed to exoteric knowledge (ilm az-zahir), it proposes an alternative and paradoxical explanation of the world, which most often is incomprehensible to exoterists" (Geoffroy 50). Interest in Sufi teaching grew in many parts of the Islamic world reaching its zenith in countries located within the ambit of Persian cultural influence.

Being estranged from God and alienated from spirituality, man finds himself lost in this world; striving to find the meaning behind his existence. His involvement in the material, rather than the spiritual, world makes him perplexed and he, consequently, loses stability in life. Such estrangement of man from God generates an impulse for man to return to his origin. This schism "is not merely the separation between the subject and the object of his perception, but also an inner division in man's selfhood" (Kirschner 161). Each individual spirit separated from the Spirit of the Divine desires to return and reunite with it. It is "due to this state of alienation that the soul longs to return to its origin" (Kirschner 125). Sufism proposes a unity or a re-unity, as it were, with the Universal Spirit, i.e. God. The Sufis embark on a journey known as the Sufi path: a path of love and devotion which leads to reunite with the Spirit of God. Hence, the Sufi aims at connecting the outer physical reality with a timeless and space-less dimension experienced only within the self. This return to the origin "necessitates a sort of oneness, a negation of self, and aims at uniting this self with God; that is, extinguishing himself in Him" (Geoffroy 14). In Sufism, this kind of communion with the Divine is referred to as 'fanaa' or annihilation, i.e. annihilation of the self in the ultimate Being. Annihilation takes place as a result of "the intoxication of immersion in the divine Presence, in an entire loss of self-consciousness" (Geofrroy 14). During this process or state of unity or immersion, the Sufi does not see anything outside his own self and is not aware of the physical reality. This is called Divine intoxication, which, in Sufism, is the fruit of finding God. This "transitory state of inebriety then becomes 'the prelude' to a sober state, known as, 'baqaa' or permanence, where the Sufi sees Him in everything" (Geoffroy 15). The Sufi heart, thus, becomes "an unstained mirror that reflects the Divine light and reveal it to others" (Schimmal 13). The great Sufi Muhyi'd-Din Ibn Arabi used to pray, uttering these words: "Enter me, O Lord, into the deep of the Ocean of thine Infinite Oneness" (qtd in Sharda 23).

As per Sufi teachings, finding one's way in this world is not to be realized via the external world, but in the inner landscape of the soul. The "spiritual quest takes us deep into the hidden places of the soul, across the rivers, mountains, and great oceans of the psyche" (Vaughan-Lee xii). St. Augustine once said that "people travel to wonder at the height of the mountains, at the huge waves of the sea, at the long compass of rivers, at the vast compass of the ocean, at the circular motion of the stars, and they pass by themselves without wondering" (qtd in Vaughan-Lee xii). Inner transformation and truth-seeking is a flight that begins from within to without, not vice versa. In Sufism, being "was of an undifferentiated unity interrupted by material creation which resulted in the separation of humanity (as lover) from God (as Beloved)" (Dabashi 381) and that is why when the self searches for truth, it has to apprehend that the answer lies within its boundaries. The Sufi path is "subversive rather than confrontational. It works from within, from the self which lives in the very depths of the unconscious, with secret recesses of the heart" (Vaughan-Lee 4). As for the mind, from a spiritual perspective, it has its own limitations. It is known as "the slayer of the Real, for it stands between the seeker and the Real self, while its constant chatter defers us to our inner voice" (Vaughan-Lee 1-2). Spiritual truth "embraces rather than separates the opposites. Truth is not on the level of duality, but the experience of oneness" (VaughanLee 2). A real Sufi always seeks to understand the essence of truth, reality, and his origin and he is well-aware that he will find explanations for all his questions within, not without. Sufism is spiritualism against materialism. As an ascetic philosophy, "Sufism guarantees redemption from miseries of life, the knowledge as redeemer is identified with God" (Sharda 23). Thus, according to Sufism, the supreme Truth or Reality is God.

One way of identifying with the Divine is through contemplation or meditation, or at-tafakkur. One hour, or even one moment of meditation "is worth more than the good works accomplished by the two species of beings endowed with weight" (Burckhandt 95). In the act of contemplation, the Sufi confirms that there is no reality but God. In fact, at-tafakkur "constitutes the inner structure of epistemic ascent in Sufism, which represents a very complex spiritual process with the highest goal being the mystical realization of God" (Al-Daghistani); it is a testimony of the oneness of the existence of an absolute, divine Reality. In his book Contemplation: An Islamic Psycho Spiritual Study, Malik Badri explains that "the way to a cognizance of God is to glorify Him in His creation, to contemplate His wonderful works, to understand the wisdom in His various inventions" (27). Badri adds that God gifted men with minds in order to think of His creatures and contemplate and learn from what wonders entrusted in His creation (27). There are different kinds of contemplation: "from the stage of observing creation and wondering about its beauty and uniqueness, to the stage in 
which the contemplator related his spiritual and aesthetic experience of creation with the almighty Creator Himself, and finally, to the stage which entirely transcends the boundaries between creation and Creator" (Al-Daghistani). Contemplation, thus, is not only a spiritual activity that is not linked with any cognitive dimensions, but is rather an amalgamation of cognition, meditation, and imagination. By means of imagination, the contemplator "passes from the perceived image ... (al-mithal) to the spiritual "reality" (alhaqiqa) which the image bears from, the fading "world of senses" (alam-al-hiss) into the eternal "world of dominion" (alam-al-malakut)" (Tamer 86). Hence, the contemplator, by means of imagination, passes from the visible image to the reality beyond it. The famous Sufi, Al-Ghazali, "ascribes to imagination a mediator role between sensual perception and knowledge of truth" (Tamer 87). Imagination and contemplation are crucial to the Sufi in his path towards reaching divine Truth.

The Romantic period was an era of spiritual expansion and the Romantics pursued a sense of mystical oneness with the Divine. In fact, the Romantics were inspired and influenced by the Sufis because their teachings suited their aims and goals. The Sufis and the Romantics share common poetic concerns and this becomes visible through their similar themes and forms. In his article, "Sufism, Christian Mysticism, and Romanticism", Naji Oueijan maintains that to the Romantics, "perhaps the most appealing and attractive feature of Sufism was the fact that it was a vehicle for higher literature, poetry" (15). Needless to say that almost all Sufi mystics are Sufi poets; they believed poetry was the highest form of literature (15). Oueijan adds that in Sufism and Romanticism, "separation from the self involves a detachment from the material self and other and an attachment to or fusion of the spiritual self with the spiritual other, the former involves pain and suffering, the latter redemption and reconciliation" (17-8). English Romantic literature has been often described in terms of "an individual life journey in solitude and in search of 'the unknown point of origin', toward a revelatory reintegration and unified state" (Ciecko 6). In his Encyclopedia of the Romantic Era, 1760-1850, Christopher Murray suggests that the Romantic Neoplatonic philosophy was founded on the principle that "all creation originally existed in a harmonious unity" (1129). He goes on to explicate that since human beings are separated from original unity, we all carry some part of the original 'one' within ourselves. This original one leads us to "sense the cosmos within ourselves and provokes in us the divine impulse for reunification of the cosmos" (1129). The renowned Romantic poet, Percy Bysshe Shelley, believed "in a Soul of the Universe, a Spirit in which all things live and move and have their being; which ... is unnamable, inconceivable even to man, for the deep truth is imageless" (Spugeon 35). Shelley's most passionate desire was "for the mystical fusion of his own personality with this Spirit, this object of worship and adoration" (Spugeon 35). He believes that even death is not as disastrous as it may seem since it will unveil this separateness between himself and the Ideal Spirit, which he believes is his true life. This sense of unity with the Divine is most strongly apparent in Adonais as well as The Hymn to Intellectual Beauty which is, in some way, "Shelley's clearest and most obvious expression of his devotion to the Spirit of Ideal Beauty, its reality to him, and his vow of dedication to its service" (Spugeon 35-6). It becomes clear, thus, that spiritual unity with the Divine is also part of the Romantic agenda.

In his book Romanticism and Anti-Self Consciousness, Geoffrey Hartman proposes that there are two types of self in Romanticism, "the self-conscious self and that self within the self" (184). In an endeavour to find the latter (the self within the self), the Romantic subject "seeks a form of self-oblivion or self-annihilation in order to get rid of the former, that is the self or consciousness that alienates him from this real self and imposes the burden of a self which ... death or a return to the state of nature might dissolve" (Lussier). This second type of self is tremendously similar to the Sufi soul discussed earlier. The fact that the Romantics apply the same process of self-annihilation is a reminder of the Sufi 'fanaa' in which the soul connects with the divine Spirit. The real self, or the 'self-conscious' self as described by Hartman, is the one associated with the physical world and which the Sufis denigrate and usually dispense with. Thus, the second step is embedded in a desire by the self for communion with the other (God). This desire for connection engenders a sense of continuous yearning to return. This is what Hartman refers to as "the Romantic fantasy of a return to the imaginary bliss of non-separateness, a unity of being, through a process of going beyond self-consciousness which is the product of a division in the self" (183). According to Leonard Lewisohn, "the only way for the Romantic subject to eventually overcome this alienation seems to be the idealized love object which consequently leads to either symbolic or actual death" (514). In his poem Milton, William Blake says:

I will go down to self annihilation and eternal death,

Lest the Last Judgement come \& find me unannihilate

And I be seiz'd \& giv'n into the hands of my own Selfhood. (532)

Similarly, the Sufi poet, Rumi, maintains that "the best sort of existence is found only when a man annihilate his 'self'" (Lewisohn 209). In his Mathnawi, Rumi explains that "the mystic may seem to be 'annihilated', his 'annihilation" (fanaa) is in fact a higher form of "being-in-God (baqaa)" (Lewisohn 209). Through annihilation, for Romantics and Sufis alike, one remains subsistent in God.

The genuine objectives of romanticism are actually spiritual, if not mystic, in nature. In the Romantic point of view, it is "heightened imagination which leads a poet to the mystic perception of the constant behind the flux, the infinite behind the finite, the eternal behind the ephemeral, and the transcendental behind the sensory" (Mukherjee 135). In his Biographia Literaria, Coleridge explains that imagination is "a repetition in the finite mind of the eternal act of creation in the finite I AM" (304). Shelley "regarded the human imagination as a divine creative force" (Spugeon 36). In his Prelude, William Wordsworth emphasizes the power of the imagination by saying that "imagination, which, in truth,/Is but another name for absolute power/And clearest insight, 
amplitude of mind,/And Reason in her most exalted mood" (12). For all Romantic writers, imagination is the fundamental ground for human knowledge. For the Romantics, as well as the Sufis, "the powers of passion, feeling, reason and imagination themselves comprise the quintessence of Being itself, because existence itself is thought" (Lewisohn 204). Imagination is the faculty that "allows the human person, whether instinctively or consciously, to shape the world into meaning, much as in the beginning God shaped chaos into cosmos" (Barth 1). In her article "The Concept of "Romanticism' in Literary History”, Rene Wellek points out that imagination, for the Romantics, was "not merely the power of visualization, somewhere in between sense and reason, as it had been for Aristotle ... but a creative power by which the mind 'gains insight into reality', reads nature as a symbol of something behind or within nature" (237-8). The same idea is applied to Sufis who hold similar views in regards to the power of the imagination. Therefore, both Sufi and Romantic poets confirm that imagination has the power to animate and (re)generate the cosmos.

\section{Keat's Ode to a Nightingale}

Unlike Byron, Coleridge, or Wordsworth, John Keats never acknowledged reading Arabic or Persian works. However, a thorough examination of his ode shows that he was influenced by orientalist writings to some degree. "Ode to a Nightingale' is considered by far one of Keats' widely discussed poems. On the descriptive level, the speaker of the poem addresses a nightingale and seems to be in dire desire to reunite with that bird. Many implications arise as to the nightingale's whereabouts hinting at possible prior meetings between the speaker and the bird which makes the speaker request re-connection at various times. As per the speaker's depiction, the world of the nightingale is quite peaceful, with no worries or pressures of any kind compared to the real world where the speaker, and all humanity as it were, lives. The key morass on which the poem is built is whether the nightingale's world is real or illusory since the speaker refers to his unconscious state at the beginning of the poem, confirms it in the middle, and questions it at the end. This alpha state of mind, if one can call it that way, makes the poet's physical awareness in doubt and this makes the readers dubious in return as to whether the nightingale is real or is only an invention of the poet's dizzy consciousness. As is clear, the poem describes a rare experience, remote from the common place, an experience within, and not without, as will be elaborated in the coming pages.

In the first stanza, the poet expresses his senseless and painful state: "My heart aches, and a drowsy numbness pains/My sense" (L1-2). He elucidates that state could be the cause of him drinking 'hemlock', 'opium', or even from the ${ }^{2}$ 'Lethe'. In any case, the poet's desire to forget and be forgotten is evident in these lines, along with a sense of drowsiness or insentience due to his aches and pains. The "oxymoronic blending of intense pleasure and numbing pain, that is, the sense of painful pleasure, conveys a peculiar state of mind distinct from everyday reality and prepares the poet for a visionary flight" (Khan 83). At this moment, the speaker begins to lose contact with his real - physical- self gradually and undergo a journey with the nightingale. In line five, he talks directly to the nightingale and the quotation marks testify to the bird's presence at that specific moment. The fact that the nightingale appears so suddenly suggests the pre-existence of the bird from the start and highlights the poet's tight affinity with it:

'Tis not through envy of thy happy lot,

But being too happy in thine happiness, -

Keats is positive that the nightingale is happy, and his only desire is to unite with it and share this happiness. He refers to the nightingale as a 'dryad' (L7) who moves freely without restraints, creating melodies and transmitting positive vibes to all the places he visits: 'That thou, lightwinged Dryad of the trees / In some melodious plot / Of beechen green and shadows numberless, /Singest of summer in full-throated ease" (L7-10). Associating the nightingale's music with the trees and the 'beechen green' suggests a smooth shift from the reality of the poet (being in pain) to a rather heavenly realm, full of freedom and happiness. This stanza stresses the poet's avidity to escape from this world (through hemlock or opium) and resort to the nightingale to free him from his chains and flee him to his world which appears divine and dream-like.

Being in a state between reality and dream, and having listened to the nightingale's melodious notes - that come from afar - the poet wants, in the second stanza, to emerge into total loss of consciousness as by severing all contact with his physical self, he will be deported wholly to the nightingale's realm. He wishes to drink beer, to dance, and sing in full mirth in an attempt to be intoxicated and thus "leave the world unseen,/And with thee fade away into the forest dim" (L19-20). The only way to join the bird is to be entirely unaware of his physical existence and this makes apparent that the nightingale is not part of the physical world, but is rather a metaphysical entity that requires a total loss of self or annihilation (in Sufi terms) if one aspires to join it.

In the third stanza, the poet depicts the ruthless reality of the physical world and highlights that his longing to 'fade away in the forest dim' with the nightingale is because he is scared to fade away in a different manner: "the melancholy dissolutions of change and physical decay" (Fogle 213). The realm of stanza three is diametrically opposed to that of stanza two in that it gives the readers a picture of common, stern reality in which the life of man is composed of: volatility and frustration. The "contrast between reality and transcendence, advance and withdrawal, is brought to focus by what Leavis calls "the prosaic matter-of-fact" tone of this "completely disintoxicated and disenchanted" stanza" (Khan 84).Keats “does not specify precisely what he wishes to escape; biographically, it could have been any number of problems" (Ober 875) or even his brother's death, but he illuminates the brutal reality in which one lives. Contemplation of the cantankerous trajectories man has to follow or even stumble on in this world is a common Romantic theme. However, "Keat's presentation of the condition of human suffering is different from the lyric cries of pain in his fellow Romantics ... for he does not directly speak out his own plight from which he consciously attempts to disengage himself" (Khan 85). Keats achieves his 
purgation or 'catharsis' through negative capability, i.e. immersing in total annihilation or self-loss and observing this miserable human condition from a distance.

The first line of the fourth stanza: 'Away! Away! For I will fly to thee' highlights the urgency and the speed with which the poet wants to arrive at his sought-for destination. However, he makes it clear that he will not resort to 'Bacchus' (the Greek God of wine) to help him out, as it was implicated earlier, but would rather fly on 'the viewless wings of Poesy". Poetry, thence, becomes a more sublime means through which Keats would reach full intoxication in an attempt to forget this world entirely. This choice stresses the poet's transcendental odyssey and negates any speculations of a base, worldly form of intoxication. The abrupt line: 'Already with thee!' complicates the situation by highlighting that the poet has already been united with the nightingale from a long time and as soon as he realizes this connection, he loses his vision, yet, his senses of smell and hearing are being gratified. Sentences and phrases such as "there is no light", "I cannot see", "embalmed darkness", "darkling I listen" seem to pervade the fourth and the fifth stanzas, along with vivid descriptions of the nightingale's world. Similarly, Rumi urges us to delve into darkness as in it, the source of light is instilled:

Though we sleep and rest in the dark,

Doesn't the dark contain the water of life?

Be refreshed in the darkness.

Doesn't a moment of silence restore beauty to the voice? Opposites manifest through opposites:

With black core of the heart

God created the eternal light of love. (Anthology 103)

The "forest scene is Romantically picturesque without being really pictorial: one does not visualize it, but its composition is describable in visual metaphor" (Fogle 215). Although the poet loses his sense of sight, he is still able to imagine the green colour that dominates the landscape and to smell and feel the flowers that surround the place. What is also noticeable is Keats' reference to different types of roses such as: "hawthron", "eglantine", "violets", and, muskrose", hence creating a close rapport between the nightingale and the roses. It becomes obvious, at that specific moment in the poem that the speaker has not flown away from his physical self, but has, in contrast, flown into the deepest places of his soul.

The most prevalent symbols in Sufi literature is that of the nightingale and the rose. The rose or the gul represents God's perfect beauty and the nightingale or the bulbul refers to the soul. The symbol of the soul bird was the centre of Attar's Manteq ul-Teyr (The Conference of the Birds) written in 1177. In one of his poems, Rumi "symbolizes the soul as sweet-voiced birds, which are imprisoned in cage" (Shah 109): "Only sweet-voiced birds are imprisoned,/Owls are not kept in cages" (qtd in Shah 109). The incarcerated bird is a reference to the soul that reflects the beauty of its Creator. Additionally, the colour green, which is a recurrent symbol in this poem is the colour of nature, and is also the "colour of the realization of God, the "Emerald Rock" which exists on the top of the mystical Sinai, the mountain which the exile must climb when he is summoned at last to return home, to return to himself' (Vaughan-Lee 15). In his poem 'Stay Close, My Heart',
Rumi writes: “And with your soul always green, you'll grow into a tall tree/Flowering always with sweet light fruit, whose growth is interior" (Anthology 166). Thus, it becomes explicable that Keats was not describing the drunkenness of Bacchus, but the intoxication that he yearns is that of a higher order that could go together with poetry. Poetry, with its viewless wings, becomes a potential vehicle into the subtle depths of the unseen, where truth and beauty reside eternally with God.

In the sixth and seventh stanzas, Keats introduces the idea of death but provides a rather opposing meaning than the one defined in the third stanza and appears to be identifying with death and accepting it wholeheartedly:

I have been half in love with easeful Death,

Call'd him soft names in many a mused rhyme,

To take into the air my quiet breath;

Now more than ever seems it rich to die,

To cease upon the midnight with no pain.

While thou art pouring forth thy soul abroad

In such an ecstasy! (L51-6)

Keats "celebrates death as an 'easeful', rich, painless event, not as the denial of life but the creative potentiality" (Nagar 222). Death, here, opens the bare possibility of a new life, the life desired by the Sufi, that is because the death he is referring to is the death of the body, not of the soul as it were. In his poem 'Life and Death', Rumi speculates on death and reassures his readers: 'You mustn't be afraid of death/You're a deathless soul" (Spiritual 51). The speaker tries to "make his presence in this world permanent through the metaphorical equation of this presence with dying" (Huhn 166). Keats severs any and every relation with the outer world and creates a parallel world, within, that appears to be better and more tolerable. Death is "characterized by the same attributes (and isotopies) of painlessness, harmony, timelessness, of mystic union as the existence of the nightingale" (Huhn 166). It is only when the body (external consciousness and awareness) does not exist, that his spirit becomes free and flies in ecstasy. The death theme, thus, "turns to a basis for the immortality of the nightingale" (Fogle 216): "Thou wast not born for death, immortal Bird!" (L60). The identification with the nightingale - being a synecdoche for the soul of the speaker - makes the two entities share immortality. Within the depths of duality, the speaker discovers the reality of Oneness. Only when he dissolves with the nightingale, the speaker finds his long-sought-for desire and reconnects with the most Supreme Being, i.e., through negativity (death), one finds what he has been searching for. The word 'half' in 'I have been half in love with easeful Death' (L51) testifies to this duality and stresses the speaker's full awareness of his divided being and his attempts at unifying it. This is clarified through the use of the word 'ecstasy' which suggests "an intensification of emotion so powerful as to produce a trancelike dissociation from all but the single overpowering feeling" ("ecstasy"). The soul, or the nightingale, is enjoying a trance-like feeling after getting rid of its conscious half and splitting itself from physical reality. The raptures and exultations experienced by the spirit attest to the state of contentment resulting from the final unity with God and the liberty the soul feels at last. According to William Hazlitt, "to be happy is to be rapt into a sort of oneness, into a fellowship of essence and free of space, 
to be freed, that is, from the individual experience and to be swept into the vast and infinitely various flood of emotion in the universe" (qtd in Spens 237-8). Sufism links spiritual growth to gulping the power of death, not evading it, into a higher, more transcendental life, thereby rendering life "fearless in the face of finitude" (Perriera 261).

The last stanza of the poem is brimming with words that denote loneliness, sadness, and farewell. The speaker is getting gradually detached from the nightingale and is in the process of gaining his awareness of the external, tantalizing reality: "Forlorn! The very word is like a bell / To toll me back from thee to my sole self!" (L70-1). The pun in sole / soul continues the dichotomy started at the beginning and demonstrates the poet's capacity at differentiating between his 'soul' and his being or existence. He will now be brought back to reality and will abandon the nightingale's world (or is the nightingale who will abandon him?). The repetition of the word 'adieu' three times in this stanza highlights the image of the poet who is struggling to remain unconscious when his soul is awake in another world hinting at the possible brevity of the experience per se. As the sound of the nightingale's song begins to fade, the speaker begins to be more aware of his physical existence. The fading away of the nightingale' musical notes "past the near meadows, over the still stream,/up the hill-side; and now "tis buried deep/in the next valley-glades" (L75-7) is opposed to the speaker's quasi-awakening consciousness state. As soon as he regains his full perception, the speaker asks: 'Was it a vision, or a waking dream?/Fled is that music: - Do I wake or sleep?" (L78-9). These questions "are objective in that they portray rather than abstract from Keat's state of mind" (Fogle 218). Like the beginning of the poem, these questions propose an analogous situation where the poet was in pain; feeling dizzy and drowsy. However, in this last stanza, it is not the miserable reality of living that made him in ache, but it is the disconnectedness and obliteration from the nightingale - his soul - that put him in such a plaintive state of being. In one of his poems addressing a nightingale, Hafiz expresses his profound attachment to the nightingale: "Beloved! I have lost myself in lovesickness for you,/In your heart, I sail as safely as in Noah's ark" (6). The feelings or security and warmth are lost due to this potent split forcing the speaker to return to his earlier state, when he was not fully aware whether he was awake or dreaming, highlighting a state of a wake-in-dream existence. It does not matter whether Keats awakes or sleeps, because he can renew his journey and return to the nightingale's world whenever he pleases.

'Ode to a Nightingale' is a poem that stresses the importance of the metaphysical dimension of reality. The obstreperous world is abundant with misery, tribulation, and desolation that one could hardly handle. The speaker attempts to find a way through which he could escape from such a miserable world and reconnect with the nightingale. A pure Sufi experience, the speaker aspires to reunite with God through divine intoxication, as step one, followed by self-loss or annihilation, as the second step. After finally getting united with the soul (God), the speaker begins his odyssey within aided by his quintessential sensations of beauty and truth. It is through the death of his self-knowledge and self-consciousness that he finds his real life. As soon as his awareness is fully regained, the speaker begins questioning his state of being and becomes uncertain whether that experience took place or is only part of his imagination. However, it is clear, especially in the ultimate stanza, that the "oneness with the universe, with the divine Fellowship has been snapt, and he returns to earth, to imprisonment in his own individuality" (Spens 236). Thus, Keats indulged into a flight from the real world into the world of the soul (by means of taffakkur or imagination) and then returned to actuality. Watson states that this "pattern of a ${ }^{3}$ going-out and a return is common in Romantic poetry" (365). However, this return is not futile in the sense that the poet eventually realizes the impossibility of fleeing the external world - "the fact of the physicality of [the] human condition and hence human mortality and the humanly unreachable state of pure joy and complete perfection respectively" (Khan 82). Perfection and utter happiness were felt only when the poet managed, even for a short period of time, to forget the outer reality and indulge into activities related to the inner one. This pilgrimage, if one can name it as such, leads the pilgrim back to his earthly reality but only after allowing him to penetrate into the deepest dwellings of his soul and opening his eyes to the pleasures felt through unity, i.e. via divine oneness.

\section{CONCLUSION}

This research paper postulates various analogies between Sufism and Romanticism. Both trends seem to share their interest in the immateriality of this world. The soul is more significant than the body because through the soul, one could reach oneness and unity with the Supreme Being. Contemplation, inner vision, imagination, and speculation are the key tenets on which the two schools are built. Keat's 'Ode to a Nightingale' provides a good example of a Sufi inner journey through which the poet was able to reconnect and reunite with God in a transcendental world that totally abjures the physical world and dissociates with all of its precepts. Through the palpable contrasts between the world of the nightingale and the real world, the speaker manages to showcase the differences between the world we live in and the world we should be living in. Sufism and Romanticism share many ideologies and thoughts being both apostles for a noetic philosophy that bears crucial significance to the metaphysical and the sublime.

\section{END NOTES}

1. This paper does not claim that there are no differences between the ideologies of Romanticism and Sufism but rather focuses on the similarities only to highlight the parity between Romanticism and Islamic esotericism in many aspects and to pave the way for a Sufi reading of Keat" $\mathrm{s}$ poem as a case study.

2. Lethe is "one of the rivers in Hades. The water of this river, if drunk, caused forgetfulness. So, the dead were required to drink in waters to obliterate memories of their past life." (Coleman 617).

3. Watson refers to Keates journey as a flight without and then a return, however, the researcher highlights that the flight underwent by the poet is a flight within, which makes Keat"s experience a unique one. 


\section{REFERENCES}

Attar, Samar. Borrowed Imagination: The British Romantic Poets and the Arabic-Islamic Sources. London: Lexington, 2014.

Al-Daghistani, Raid. "Taffakkur and Tadthakkur - Two Techniques of Islamic Spirituality." Kind Logos. May 2016. 13 March 2017. Web.

Angha, Nahid. "Practical Sufism and Philosophical Sufism". International Association of Sufism. 6 March 2017. Web.

Badri, Malik. Contemplation: An Islamic Psychospiritual Study. London: International Institute of Islamic Thought, 2000. Print.

Hossein, Nasr. "Persian Sufi Literature: Its Spiritual and Cultural Significance". Classical Persian Sufism: From Its Origins to Rumi. Ed. Leonard Lewisohn. London \& NY: Khaniqahi Nimatullahi Publications, 1992. 110. Print.

Barth, J. Robert. Romanticism and Transcendence: William Wordsworth, Coleridge, and the Religious Imagination. Missouri: U of Missouri P, 2003. Print.

Blake, William. Blake: The Completed Poems. Ed. W.H. Stevenson. NY: Routledge, 2014. Print.

Burkhardt, Titus. Introduction to Sufi Doctrine. Indiana: World Wisdom, 2008. Print.

Ciecko, Anne T. “Androgyny”. Encyclopedia of Romanticism: Culture in Britain, 1780s-1830s. Ed. Laura Daburdo. Oxford: Routledge, 2010. Print.

Coleman, J.A. Dictionary of Mythology. London: Arcturus P. Limited, 2007. Print.

Dabashi, Hamid. "Ayn al. Qudat Hamadani and the Intellectual Climate of his Times." History of Islamic Philosophy. Ed. Sayyed Hossein Nasr and Oliver Leaman. NY \& London: Routledge, 2002. 374-419. Print.

"Ecstasy". Merriam-Webster.com. Merriam Webster, 2011. 12 December 2017. Web.

Fogle, Richard Harter. "Keat's Ode to a Nightingale". PMLA 68 (1953): 211-222. Print.

Geoffroy, Eric. “Approaching Sufism”. Sufism: Love and Wisdom. Ed. Jean-Louis Michon and Roger Gaetani. Indiana: World Wisdom, 2006. Print.

Hartman, Geoffrey, "Romanticism and Anti-Self Consciousness". The Geoffrey Hartman Reader. Ed. Geoffrey H. Hartman and Daniel T. O'Hara. Edinburgh: Edinburgh U P, 2004. Print.

Huhn, Peter. "Plotting the Lyric: Forms of Narration Poetry". Theory into Poetry: New Approaches to the Lyric. Ed. Eva Muller-Zettlemann and Margarete Rubik. Frankfurt: Rodopi, 2005. Print.

Keats, John. The Letters of John Keats. Ed. H.E. Rollins. Cambridge: Cambridge UP, 1958. Print.

- -. Selected Poetry. Ed. Elizabeth Cook. NY: Oxford UP, 1998. Print.

Khan, Jalal Uddin. “Keat's 'Ode to a Nightingale': An Appreciation in Keatsian Aesthetics with Possible Sources and Analogues". Dogus Univetsitesi Dergisi 6 (2002): 77-96. Print.

Kirschner, Suzanne R. The Religious and Romantic Origins of Psychoanalysis: Individuation and Integration in Post-Freudian Theory. Cambridge: Cambridge UP, 1996. Print.

Lewisohon, Leonard. "Romantic Love is Islam". Encyclopedia of Love in World Religion. Ed. Yudit Kornberg. Greenberg: California ABC-CL10, 2008. Print.

Lussier, Mark. "Enlightenment East and West: An Introduction to Romanticism and Buddhism". Romantic Circles. February 2007. 4 February 2016. Web.

Moore, Thomas. Letters and Journals of Lord Byron. Project Guttenberg. London: Murray, 1830. Web.

Mukherjee, Dipanjoy. "A Monarch of Mysticism: Re-reading Wordsworth". Research Journal of English Language and Literature 3 (2015): 134-9. Web.

Murray, Christopher John. Encyclopedia of the Romantic Era, 1760-1850. London: Fitzroy Dearborn, 2004. Print.

Nagar, Anupam. Recritiquing John Keats. New Delhi: Sarup \& Sons, 2005. Print.

Ober, William B. "Drowsed with the Fume of Poppies: Opium and John Keats". Bulletin of the New York Academy of Medicine 44 (1968): 862-81. Print.

Oueijan, Naji. "Sufism, Christian Mysticism and Romanticism". PALMA 7 (2001): 9-21. Print.

Perreira, Todd L. "Die Before you Die: Death Meditation as Spiritual Technology of the Self in Islam and Buddhism". The Muslim World 100 (2010): 247-267. Print.

Rumi, Jalal al-Din. An Anthology of Translations of Mevlana Jalal al-Din Rumi: The Rumi Collection. Ed. Kabir Helninski. Colorado: Shambhala P, 2005. Print.

- -. The Spiritual Poems of Rumi. Trans. Nader Khalili. Massachusetts: Wellfleet P, 2018. Print.

Schimmel, Annemarie. Deciphering the Signs of God: A Phenomenological Approach to Islam. Albany: SUNY, 1994. Print.

Shah, Idries. The Way of the Sufi. New Delhi: Rupa P., 2007. Print.

Sharda, S.R. Sufi Thought: Its Development in Panjab and Its Impact on Panjabi Literature. From Baba Farid to AD 1850. New Delhi: Murshiram Manoharal, 1998. Print.

Shelley, Percy Bysshe. Adonais. Aukland: The Floating Press, 2010. Print.

Spens, Janet. “A Study of Keat's Ode to a Nightingale'. The Review of English Studies 3 (1952): 234-243. Print.

Spugein, Caroline F.E. Mysticism in English Literature. Cambridge: Cambridge UP, 2011. Print.

Stoddart, William and Nicholson R.A. The Mystical Doctrines and the Idea of Personality. Delhi: Adam Publishers, 1998. Print.

Tamer, Georges. Contributor. Islam and Rationality: The Impact of Al-Ghazali. Papers Collected on His 900 th Anniversary. Vol. 1. BRILL, 2015. 2 April 2016. Web.

Watson, J.R. English Poetry of the Romantic Period 17891830. London \& NY: Longman, 1992. Print.

Wellek, Rene. 'The Concept of 'Romanticism' in Literary History". Comparative Literature 1 (1949): 1-23. Print.

Wordsworth, William. The Collected Poems of William Wordsworth. London: WW Editions Limited, Cumberland House, 1994. Print. 